\title{
THE USE OF POWER IN SELF AND COLLECTIVE INTERESTS OF RETAILERS AND SMALL APPAREL SUPPLIERS' RELATIONSHIPS.
}

\author{
Dr. Cagri Talay, Nottingham Trent University, UK \\ Dr. Lynn Oxborrow, Nottingham Trent University, UK \\ Professor Clare Brindley, University of Derby, UK
}

\begin{abstract}
This research investigates the power use in self and collective interests of retailers and small apparel suppliers' relationships. Our findings highlighted that power use of fast fashion retailers in self-interest and collective interest related goals are evident mainly in the areas of capability development, production processes and innovation in asymmetric relationships with Turkish apparel suppliers.
\end{abstract}

\section{INTRODUCTION}

This research aims to contribute to relationship marketing theory in industrial contexts by investigating the use of power in self and collective interests of retailers and small apparel suppliers in asymmetric relationships in Turkey.

The increasing importance of power as a determining concept in supply chain relationships has recently received much attention from researchers (Nyaga et al., 2013, Hingley et al., 2015). For several decades researchers have been interested in understanding the structure and dynamics of power, Cox et al., (2001) stated that power deserves to be the central construct in buyer-seller relationships. Moreover, the role and significance of power in supply chain relationships have been highlighted by many researchers (Benton and Maloni 2005, Kumar, 2005). However, power is still an elusive concept and the concept of power is still underdeveloped area and its scope is still too narrow (Hingley et al., 2015).

The concept of power is widespread and it can be easily observed in supplier-retailer studies because in asymmetric exchange relationships, retailers are the powerful side and they are able to set the rules of the game (Hingley et al., 2015). A number of researchers in supply chains (Nyaga et al., 2013, Rindt and Mouzas, 2015) have explored power asymmetry. In asymmetric supplier-buyer relationships, the powerful partner applies its power in two main areas: the strategic and operational areas of the weaker party. This means that the weaker party accepts the control of the powerful party in its business activities in both areas (Johnsen and Ford, 2008). Furthermore, power asymmetry in supplier-buyer relationships affects weaker party's adaptive and collaborative behaviour, and it may provide more chance to the powerful partner to take opportunities in the relationships (Nyaga et al., 2013).

However, it has been highlighted that existing models and classifications do not sufficiently capture the characteristics in buyer-supplier relationships (Holmlund, 2004). Therefore, further research is needed to fully comprehend the constructions and methods involved in buyer-supplier relationships (Munksgaard, Johnsen and Patterson, 2015).

This research has important implications for fast fashion suppliers' managers, which are regularly dealing with power use by large buyers in their self and collective interests in relationships because retailers have an increasing power in the market (Hines and McGovan, 2005). There is still a lack of research in the apparel supply chain relationships in relation to increasing exertion of power by retailers (Oxborrow and Brindley, 2014). Furthermore, power use influence business activities of small supplier firms by restricting, limiting, attracting and encouraging them (Pulles 2014). Therefore, this study has focused on how self and collective interests are evident and employed in order to develop long term and beneficial co-operations. The following research question has been addressed in this study:

How fast fashion retailers use power in self and collective interests in asymmetric relationships with small apparel suppliers based in Turkey? 


\section{LITERATURE REVIEW}

The Increasing importance of power as a determining concept in supply chain relationships has recently received much attention from researchers (Nyaga et al., 2013, Pulles et al., 2014, Maglaras et al., 2015, Chicksand, 2015, Hingley et al., 2015). For a several decades a lot of researchers have been interested in understanding the structure and dynamics of power, Cox et al., (2001) stated that power deserves to be the central construct in buyer-seller relationships.

Lacoste and Johnsen (2014) have stated that power can also be used by suppliers by focusing on business processes of customers and creating inter-dependencies that is so called countervailing power. However, a negative effect of power asymmetry was not an agreed view universally. There is also a body of research that highlights positives of power asymmetry. Hingley (2005) argues that asymmetry need not be a barrier to develop a relationship; indeed, the relationship may provide mutual benefits, which override any possible negative effects of the power asymmetry.

Meehan and Wright (2012) have reported that there is a consensus among authors, there is a dramatic swift in the balance in power, from suppliers to retailers. This may have some consequences for small suppliers by affecting their competitive advantage (Hines and McGovan, 2005). This could be disadvantaged in deals with large retailers (Hingley, 2005). The recent findings shows that move into private label goods, produce exclusively for retailers. In such conditions, the retailers take control of branding over the supplier (Meehan and Wright, 2012).

\section{Power Asymmetry and The Relational View}

Power/dependence relationships it is necessary to have balance, Emerson (1962) commended that if any one party attempts to gain more power, then the other party will try to balance that power against its partner. This is an ongoing process. Cook and Emerson (1978) stated that the long term effectiveness of power can be seen as a control mechanism. Indeed, they were of the opinion that the powerful party will exploit the weaker party meaning that there is imbalanced power in the relationship, thus resulting in less cooperation and high levels of conflict (Dwyer et al., 1987).

The buyer relationships that have developed are large company dominated with a focus on cost reduction rather than responsiveness with trust and commitment not easily achieved (Johnsen and Ford, 2006). Trust and commitment are critical to the development of mutually beneficial relationships (van Hoek, 2000). Johnsen et al. (2006; after Sako, 1998) identify varying levels of trust which emerge as commitment develops. Johnsen and Ford (2008) have found that power asymmetries affect the direction of relationships and buyers and suppliers change their position in term of this effect in long term relationships. Weaker party might have difficulties to build its own business goals, but to follow the stronger parties' decisions. Furthermore, power asymmetry jeopardises relationship development process efforts of weaker party because weaker parties gain power and overcome asymmetries as the relationship develops (Lee and Johnsen, 2012).

\section{Power Types}

Katsikeas et al. (2000:187) divided the literature on power into two distinct areas; coercive and non-coercive power. Non-coercive power is identified as building upon rewards, being legitimate, and referent, expert and informational. Coercive power uses penalty rather than reward to control another party (Benton and Maloni, 2005, and Terpent and Ashenbaum, 2012). However, Gaski (1986) has criticised this classification because it was ignoring the other effects and use of power in supply chain relationships. Moreover, power asymmetries has been considered as close to coerciveness, because coercive power take place if there is a low level of commitment and conflicting relationships where one party is strongly dependent on the other (Dwyer, 1980, Ford et al., 2003). On the other hand, it diminishes the chance of cooperation between parties and long term successes. As opposed to coercive power, non-coercive power affects the relationship positively by increasing the motivation, cooperation and offering more negotiation opportunities for the weaker party (Lacoste and Johnsen, 2014). However, our knowledge of power is still limited in supply chain 
relationships (Meehan and Wright, 2012). In addition to this, there is a limited understanding the use of powerinfast fashion particularly.

\section{Self and Collective Interests}

In dyadic relationships, effectiveness and beneficial results are related to behaviour and actions of both parties. However, conflicts are unavoidable in relationships so that they may likely to increase the level of checks over each other and controls in the relationships (Eisenhardt, 1989). Business goal alignment is highly preferred because it provides a synergy and efficiency in activities of both parties in the relationships, in addition, when the complexity increases in relationships, managing alignment even become more important (Corsaro \& Snehota, 2011). Self-interest can be defined the act of following and protecting one's own rights, on the other hand, collective interest is combining interests of both parties in a relationship (Medlin,2006). In this study, the interaction perspective leads us to explore how an interest of each party is related to business goal development, retailers and suppliers may have different interest in their cooperative business activities because of dissimilar resources.

\section{Supplier Capabilities and Power Asymmetry}

The capability of a firm is its ability to achieve against the hostility of circumstance or strong competition (Mintzberg and Quinn 1992). In dyadic relationships interaction utilize the capabilities of a company but may also determine their alteration or development over time (Ford, Hakansson and Johanson, 1986).Nevertheless, in asymmetrical relationships, suppliers' capabilities may be employed by the customers to gain benefit and alterations may only be permitted when customers have need of (Johnsen and Ford, 2002). Furthermore, Johnsen and Ford (2006) have found that small firms often have strengths and capabilities relied upon by the more powerful partner in the relationship. Similarly, small firms may influence the nature of relationships with buyers towards more symmetrical state by mainly focusing on the priorities of customers these are important to the relationships and offers competitive advantage and developing expertise in particular areas (Caniels and Gelderman, 2007). In self and collective interests of parties would be strongly related to their capabilities, this leads us to explore the relationship between these two concepts in this study.

\section{Research Design and Methods}

\section{Why the apparel supply chain in Turkey}

Since 1996, there have been no trade restrictions or duty payable for any EU trade with Turkey, a major supplier of textiles and clothing (Hauge, Oxborrow, and McAtamney, 2001). Turkey is the world's sixth biggest ready wear and apparel manufacturer and the European Union's second-largest supplier after China. Its textile industry is the world's tenth biggest and the European Union's number one supplier (Trade and Investment Centre, 2015). As the world's fourth largest clothing exporter, Turkish apparel suppliers have developed key competencies that have enabled strong partnerships with other geographically distant buyers (Tokatli and Kizilgün, 2009).

\section{Qualitative Data Collection and Sampling}

The research design adopts a multiple exploratory case study approach (Yin, 2003) to enable rich data to be gathered on the experiences of self and collective interests in asymmetric apparel supply chains. The research project will take a qualitative approach to overcome some of the methodological challenges associated with studying small supplier firms. Primary data was collected through twelve interviews with six small apparel firms. The same participants were interviewed twice due to maintain the consistency in data collection and gathering the complete set of knowledge from experts. first interview analysis enabled us to explore further into self and collective interests of small apparel suppliers and their strategies. Participants all had five or more years of experience in production processes and supply chain relations with the companies they trade. Therefore, they were able to provide depth answers to our interview questions. Participants' companies are all situated in Istanbul in Turkey. Istanbul Textile Export Association (ITKIB)'s membership data based were used for selecting suitable apparel firms. Three selection criteria were used in the selection of participant firms: a) regular exporters, b) member of ITKIB, and c) small apparel supplier firms. 


\section{Data Analysis}

NVivo 11 qualitative data analysis software was used to conduct data analysis. Interviews were taperecorded and transcribed and the data collected in Turkey was translated into English. Interviews were indepth and semi-structured, lasted between 45 minutes to 75 minutes. The transcripts were annotated to generate first level coding (Miles and Huberman, 1994). A coding tree was generated, based on emerging themes arising from the interviews based on codes for the further steps in reducing, displaying and interpreting the analysed data. The analytical approach was chosen in this research to relate the interview data to research question using themes derived from data analysis. The analysis resulted in a number of common issues, including those raised by the apparel suppliers themselves in discussion, as well as those apparent in, or in contrast to the literature. These common patterns will be discussed in findings and discussion.

\section{Findings}

Initial findings of this study have highlighted that self and collective interests of retailers and apparel suppliers are evident in the area of capability development, production processes and innovation in asymmetric relationships in order to achieve desired goals of both retailers and apparel suppliers. On the other hand, these areas of interest are determined by the retailer type and supply type, which is required from apparel suppliers. In the literature, retailers have been classified in three main categories: specialist, department stores and groceries (See Table 1). In this study, we have identified that retailer buyers of apparel suppliers that we interviewed are fit in this category

\section{Capability Development}

Specialist Retailers: developing capabilities of apparel suppliers have been considered as the most important areas in asymmetric relationships because specialist retailers are on the high end of the retailer spectrum and they offer branded products to their customers in highly competitive market. Therefore, capability development has been encouraged and supported by the retailers otherwise; retailers would not control the promised quality and service standards in highly competitive markets. These retailers use their expert noncoercive power to develop collective interest to help and support certain capability development for their suppliers such as technical, and managerial. Their orders are high variant and require scheduled time delivery in that suppliers would be playing important role in the performance and competitiveness of the retailer. Production process is another area that specialist retailers develop self-interest by using their coercive punishment power because there was not any chance to change or reverse manufactured apparels. On the other hand, innovation was the area of both parties willing to develop collective interest, which would offer retailer competitive advantage and supplier to have longer relationship with the retailer, retailers use non-coercive reward and information power to add value to their own performance and competitive advantage.

Department Stores: developing capabilities of suppliers are also important determinant for department store type of retailers but department stores were not willing to develop collective interest in asymmetric relationships with suppliers in capability development and production processes, they were more interested in pursuing self-interest in the asymmetric relationships. They mainly used coercive power over their suppliers because department stores required low variant and flexible time delivery. However, quality was the most important thing that is attached to their brand image in the market thus; there was little tolerance to any mistakes in the production processes. Their market is not as competitive as specialist retailers are. They were focusing on larger segments in the market and less competitive products. However, they preferred developing collective interest with apparel suppliers in innovation because they always want to outsource considerably new but cost effective supply from apparel suppliers. They mainly use non-coercive reward power for innovation related collective interest.

Groceries: They were mainly interested in cost and quantity in their relationships. Their orders are low to mid variant and quantities were very high compare to specialist and department store because they have large stores and they are on the low end of apparel market. Therefore, self-interest development in relationships with supplier was evident and they mainly use coercive punishment power in their relationships 
with apparel suppliers. They were the dominant power in this category with low quality requirements. Capability development and production process efficiency were mainly seen the tasks for apparel supplier and relationship investment was very high for apparel suppliers.

\section{Conclusion and Discussion}

Retailer-supplier relationships in apparel industry are asymmetric and increasing power of retailers are evident (Oxborrow and Brindley, 2014). However, increasing power of retailers in asymmetric relationships have also been found in this study as beneficial for apparel suppliers that supply to specialist and department store type retailers. Asymmetry offers development opportunities and benefits for apparel suppliers in the areas of capability development, production processes and innovation Meehan and Wright (2012), and developing collective interest with retailers (Corsaro \& Snehota, 2011). Furthermore, we found that coercive and non-coercive power use influenced business activities of small supplier firms by restricting, limiting, attracting and encouraging them in order pursue collective and self-interests in asymmetric relationships in line with (Medlin,2006 and Pulles 2014).

Power use of retailers are related to the increasing dominance, resources and position in the supply chain Meehan and Wright (2012). In addition to this, we have found that retailer type; specialist, department store and groceries, and supply type; low variant and high variant orders versus limited and flexible time requirements of orders influence power use including coercive and non-coercive in the areas of capability development, production processes and innovation.

Building on interaction view, we start to explore how retailers use power in self and collective interests in asymmetric relationships with small apparel suppliers? Our findings have also important implications for retailers and apparel suppliers. Retailers should realise that being in a powerful position is also related choosing and working with competent suppliers, their developing capabilities and competencies would be very important determinants for competitive advantage and performance. On the other hand, apparel suppliers should understand the requirements of their buyers and their market conditions in asymmetric relationships and seek to involve development of collective interests with them. This is important finding in this study that fast fashion suppliers need to understand the concept of power and its use by retailers in terms of capabilities, production process and innovation.

Furthermore, the findings in this study indicated that power use in self and collective interests in asymmetric relationships are related to capability development, production processes and innovation. These aspects can be seen to be instances of a broader recognizable set of asymmetric relationships. Self and collective interests of parties irrespective to supply chain and country might be still challenging for small suppliers in relationships with retailers as a result of integrating global supply chains and an undeniable fact of power swift from suppliers to retailers globally. Integration of global supply chains provides advantages to the fast fashion retailers such as cost, faster product development cycle and higher quality advantages that they cannot refuse to accept. On the other hand, parallel market demands in more customisation manifest those retailers to fill the demand in similar ways through integrated global supply chains. Therefore, self and collective interests in fast fashion supply chain relations may be recognized as important relational constructs for defining and understanding retailer and supplier relationships in fast fashion supply chains.

In this study, we explored self and collective goal development in asymmetric relationships by collecting data from apparel suppliers point of view but the future studies would explore the same phenomenon from both retailer and supplier sides to have a full clear picture of the dynamics of power use and its determinants. 
- Belaya, V., Gagalyuk, T., \&Hanf, J. (2009). Measuring Asymmetrical Power Distribution in Supply Chain Networks: What is the Appropriate Method? Journal of Relationship Marketing. 8, 165-193.

- Benton, W., \&Maloni,M. (2005). The influence of power driven buyer/seller relation- ships on supply chain satisfaction, Journal of Operation Management. 23(1),1-22.

- Caniels, M.C.J., \&Gelderman, C.J. (2007). Power and interdependence in buyer supplier relationships: A purchasing portfolio approach,Industrial Marketing Management. 36, 219-229.

- Chicksand, D. (2015). Partnerships: The role that power plays in shaping collaborativebuyer-supplier exchanges, Industrial Marketing Management. 48(1), 121-139.

- Corsaro, D., \& Snehota, I. (2011). Alignment and misalignment in business relationships. Industrial Marketing Management, 40(6), 1042-1054.

- Cook, K. S., and R. M. Emerson. (1978). Power, equity and commitment in exchange networks. American Sociological Review, 43: 721 - 739).

- Cox, A., Sanderson, J., \& Watson, G. (2001). Power regimes: A new perspective on managing in supply chains and networks. 10th international annual IPSERA conference ,Jonköping, Sweden. 215-227.

- Dwyer, F.R., Shurr, P.H., \& Oh, S. (1987). Developing buyer-seller relationships, Journal of Marketing.51(2), 11-27.

- Emerson, R. M. (1962). Power-Dependence Relations, American Sociological Review. 27(2), 31-41.

- Eisenhardt, K. M. (1989). Agency theory: An assessment and review. Academy of Management Review, 14(1), 57-74.

- Federations of Indian Chambers of Commerce and Industry. (2014). India-Turkey Trade and Economic Relations Prospects for The Future, A Knowledge Report,http://www.cgiistanbul.org/frontEnd/userfiles/files/IndiaTurkey\%20Trade\%20and\%20Econo mic\%20Relations(1).pdf, Accessed September 28, 2015.

- Ford, I.D.,Hakansson, H., \&Johanson, J. (1986). How do Companies Interact? Industrial Marketing and Purchasing, 1(1), 26-41.

- Ford, D.,Gadde, L. E., Hakansson, H., \&Snehota, I. (2003). Managing Business Relationships, John Wiley, Chichester.

- Gadde, Lars. E., \&Hakansson, H. (2002). Supply Network Strategies, John Wiley \& Sons LTD, Chichester.

- Gaski, J. F. (1984). The Theory of Power and Conflict in Channels of Distribution, Journal of Marketing. 48(2), 9-29.

- Hague, J., Oxborrow, L., \&McAtamney, L. (2001).Musculoskeletal disorders and work

- Hines, T.,\&McGovan, P. (2005). Supply Chain Strategies in The UK Fashion Industry-The Rhetoric of Partnership and Realities of Power, International Entrepreneurship and Management Journal. 1(4), 519-537.

- Hingley, M. K. (2005). Power to all our friends? Living with imbalance in supplier retailerRelationships,Industrial Marketing Management. 34(8), 848-858.

- Hingley, M., Angell, R., \&Lindgreen, A. (2015).The current situation and future conceptualization of power in industrial markets. Industrial Marketing Management, 48(1), 226-230.

- Johnsen, R.E. and Ford, D. (2002) Developing the concept of asymmetrical and symmetrical relationships: linking relationship characteristics and firms' capabilities. 18th Annual IMPConference, September 5th-7th, ESC, Dijon, France.

- Johnsen, R. E., \& Ford, D. (2006). Interaction capability development of smaller suppliersin relationships with larger customers. Industrial Marketing Management, 35(8),1002-1015.

- Johnsen, R.E., \& Ford, D. (2008). Exploring the concept of asymmetry: a typology for analysing customer-supplier relationships, Industrial Marketing Management. 37(4), 471-483.

- Katsikeas, C. S., Leonidou, L. C., and Morgan, R. E. (2000). Firm-Level Export Performance Assessment: Review, Evaluation and Development. Journal of the Academy of Marketing Science, 28(4), 493-511.

- Kumar, N. (2005). The power of power in supplier-retailer relationships. Industrial Marketing Management, 34(8), 863-866. 
- Lacoste, S., \&Johnsen, R. (2015). Supplier-customer relationships: A case study of power dynamics, Journal of Purchasing \& Supply Management. 21(4), 229-240.

- Lawler, E.J., Ford, R. S., \&Blegen, M.A. (1988). Coercive capability in conflict: A test of bilateral deterrence versus conflict spiral theory, Social Psychology Quarterly. 51 (2), 93-107.

- Maglaras, G., Bourlakis, M., \& Fotopoulos, C. (2015). Power-imbalanced relationships in the dyadic food chain: An empirical investigation of retailers' commercial practices with suppliers, Industrial Marketing Management. 48, 187-201.

- Medlin, C. J. (2006). Self and collective interest in business relationships. Journal of Business Research, 59(7), 858-865.

- Meehan, J., \& Wright, Gillian, H. (2012). The origins of power in buyer-seller relationships, Industrial Marketing Management. 41(1), 669-679.

- Miles, M. B., \&Huberman, A. M. (1994). Qualitative data analysis: An expanded sourcebook.London: Sage.

- Mintzberg, H., \& Quinn, J.B. (1992). The Strategy Process: Concepts and Contexts. Englewood Cliffs, Prentice Hall.

- Nyaga, Gilbert N., Lynch, Daniel, F., \& Marshal, D., Ambrose, E. (2013).Power Asymmetry, Adaptation and Collaboration in Dyadic Relationships Involving A Powerful Partner, Journal of Supply Chain Management. 49 (3), 42-65.

- Oxborrow, L., \& Brindley, C. (2014). Disintermediation in the apparel supply chain, Journal of Fashion Marketing and Management. 18(30), 252-268.

- Pulles, Niels J., Veldman, J., Schiele, H., \&Sierksma, H. (2014).Pressure or Pamper? The Effects of Power and Trust Dimensions on Supplier Resource Allocation, Journal of Supply Chain Management. 50(3), 16-36.

- Foreign and Commonwealth Office. (2014). Research and Analysis. Turkey: latest killer facts about the economy, https://www.gov.uk/government/publications/turkey-latest-killer-facts-about-theeconomy/turkey-latest-killer-facts-about-the-economy, Accessed September 29, 2015.

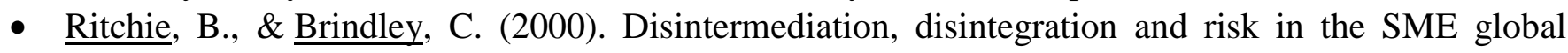
supply chain", Management Decision. 38(8), 575 - 583.

- Rindt, J., \&Mouzas, S. (2015). Exercising Power in Asymmetric Relationships: the use of private rules. 48(1), 202-213.

- Sako, M. (1998). Does trust improve business performance? in Lane, C. and Backman, R. (Ed.), Trust within and between organizations: Conceptual issues and empirical application, (pp. 88117).Oxford: Oxford University Press.

- Terpent, R., \&Ashenbaum, B. (2012). The intersection of power: Trust and Supplier Network Size: Implications for Supplier Performance, Journal of Supply Chain Management. 48(3), 52-77.

- Tokatli, N., \&Kizilgün, O. (2009). From manufacturing garments for ready-to-wear todesigning collections for fast fashion: evidence from Turkey, Environment andPlanning, 41(1), 146-162.

- $\quad$ van Hoek, R. I. (2000). Role of third party logistic services in customization through post-ponement, International Journal of Service Industry Management. 11(4), 374 - 387.

- Yin, R.K. (2003). Case study research: design and methods. Sage, London. 


\section{Table 1. Retailer Types}

Specialists: feature narrow product lines, with deep assortments

Department stores: offer a wide variety of product lines of clothing, home furnishings, household goods

Grocers (supermarkets): usually carry a relatively large variety of low-cost, low margin groceries and consumables

Source: Pearson Education (2015) and Hines and McGovan (2005).

Table 2: Company Profiles and Key Informants

\begin{tabular}{|c|c|c|c|c|c|c|}
\hline & Interviewed & Company type & Turn over & $\begin{array}{l}\text { Productio } \\
\text { n }\end{array}$ & $\begin{array}{l}\text { Customer } \\
\text { S }\end{array}$ & $\begin{array}{l}\text { Number } \\
\text { of } \\
\text { Employe } \\
\text { es }\end{array}$ \\
\hline $\begin{array}{l}\text { Compan } \\
\text { y } 1\end{array}$ & $\begin{array}{l}\text { General Manager } \\
\text { and Board } \\
\text { Member }\end{array}$ & $\begin{array}{l}\text { Manufacturer } \\
\text { exporter }\end{array}$ & $\begin{array}{l}\text { 40-50 million } \\
\text { dollars yearly }\end{array}$ & $\begin{array}{l}\text { Circular } \\
\text { knitting } \\
\text { garment } \\
\text { (sportswea } \\
\text { r) }\end{array}$ & $\begin{array}{l}\text { Specialist } \\
\text { Departme } \\
\text { nt stores }\end{array}$ & 250 \\
\hline $\begin{array}{l}\text { Compan } \\
\text { y } 2\end{array}$ & $\begin{array}{l}\text { General Manager } \\
\text { and owner }\end{array}$ & $\begin{array}{l}\text { Manufacturer } \\
\text { exporter }\end{array}$ & $\begin{array}{l}30 \text { million } \\
\text { dollars yearly }\end{array}$ & $\begin{array}{l}\text { Knitwear } \\
\text { for woman } \\
\text { and kids } \\
\text { (Jumper, } \\
\text { socks, } \\
\text { cardigan) }\end{array}$ & $\begin{array}{l}\text { Specialist } \\
\text { Departme } \\
\text { nt store } \\
\text { Grocer }\end{array}$ & 240 \\
\hline $\begin{array}{l}\text { Compan } \\
\text { y } 3\end{array}$ & $\begin{array}{l}\text { General Manager } \\
\text { and owner }\end{array}$ & $\begin{array}{l}\text { Manufacturer } \\
\text { Outsourcer } \\
\text { Exporter }\end{array}$ & $\begin{array}{l}15 \text { million } \\
\text { dollars yearly }\end{array}$ & $\begin{array}{l}\text { Knitwear } \\
\text { (T-shirts, } \\
\text { polo } \\
\text { shirts, } \\
\text { sweatshirt } \\
\text { s, tops, } \\
\text { jersey } \\
\text { jackets, } \\
\text { jersey } \\
\text { pants, } \\
\text { dresses, } \\
\text { skirts) }\end{array}$ & $\begin{array}{l}\text { Specialist } \\
\text { Departme } \\
\text { nt store }\end{array}$ & 150 \\
\hline
\end{tabular}




\begin{tabular}{|c|c|c|c|c|c|c|}
\hline $\begin{array}{l}\text { Compan } \\
\text { y } 4\end{array}$ & $\begin{array}{l}\text { General Manager } \\
\text { and Part-Owner }\end{array}$ & $\begin{array}{l}\text { Manufacturer } \\
\text { Exporter }\end{array}$ & $\begin{array}{l}20 \text { million } \\
\text { dollars yearly }\end{array}$ & $\begin{array}{l}\text { Printing, } \\
\text { embroider } \\
\text { y, Fabric } \\
\text { Knitting } \\
\text { and } \\
\text { Cutting; } \\
\text { all done in } \\
\text { one house } \\
\text { (Mid age } \\
\text { woman } \\
\text { and man } \\
\text { fancy and } \\
\text { luxury } \\
\text { dress) }\end{array}$ & Specialist & 130 \\
\hline $\begin{array}{l}\text { Compan } \\
\text { y } 5\end{array}$ & $\begin{array}{l}\text { General Manager } \\
\text { and Owner }\end{array}$ & $\begin{array}{l}\text { Manufacturer } \\
\text { Exporter }\end{array}$ & $\begin{array}{l}15 \text { million } \\
\text { dollar yearly }\end{array}$ & $\begin{array}{l}\text { Knitting } \\
\text { Socks for } \\
\text { all genders }\end{array}$ & $\begin{array}{l}\text { Specialist } \\
\text { Departme } \\
\text { nt store }\end{array}$ & 200 \\
\hline $\begin{array}{l}\text { Compan } \\
\text { y } \\
6\end{array}$ & $\begin{array}{l}\text { General Manager } \\
\text { and Owner }\end{array}$ & $\begin{array}{l}\text { Manufacturer } \\
\text { Exporter }\end{array}$ & $\begin{array}{l}\text { 5-10 million } \\
\text { dollar yearly }\end{array}$ & Shirt & Specialist & 50 \\
\hline
\end{tabular}

